\title{
Strauss, DFM
}

University of the Free State

\section{From the "rational soul" to an unbridled "trust in reason"}

\begin{abstract}
A long-standing legacy holds that reason is the hall-mark of the human soul or mind. Whereas Greek thinking struggled with the dualism of form and matter, medieval philosophy and theology wrestled with an attempt to synthesize the Greek views (of Plato and Aristotle), with the biblical view, but got entangled in serious difficulties. The rise of the modern era added an explicit trust in reason to this tradition (nondeceiving clear and distinct thinking in Descartes), combined with the motive of logical creation. According to Kant understanding creates its laws (a priori) not out of nature, but prescribes them to nature. The transition to historicism and the linguistic turn relativised Kant's claim to universal validity - each person or society constructs its own life-world. Briefly highlighting the intrinsic inconsistency of positivism is followed by lifting out the acknowledgment that the trust in reason is not rational itself (Popper) and that one has to believe in something before one can justify something else (Stegmüller). In conclusion a brief example is given of such an assumption with reference to the a priori continuity postulate of (neo-)Darwinism nature does not make jumps (natura non facit saltum).
\end{abstract}

The aim of this article is to follow a significant enduring conviction present in the intellectual history of the West which embraces all academic disciplines, including philosophy and theology. The underlying problem is that if human reason (or: rationality) is universal and objective it is impossible to explain why there does not prevail consensus in all academic disciplines. Although the term "reason" acquired multiple meanings throughout history, Paul Bernays may be right in claiming that the key factor present within rationality is found in the conceptual element. ${ }^{1}$ However. conceptual schemes are not self-contained. They display the guiding and directing influence of ultimate commitments. Of course anything within creation may be elevated to the level of what is considered to be divine. The rich diversity within creation provide apostate thinking with endless possibilities in this regard. Yet the commitment to reason, although passing through many variations, managed to exercise its influence up to the present. Whenever something within creation is reified or absolutised, it is a sign of idolatry. Christian intellectual endeavours that want to be as radical as the Bible ought to accept, in the words of Wolters, "as a point of departure, that every creature of God is good, and that sin and salvation are matters of opposing religious direction, not of good and evil sectors of the created order. All aspects of created life and reality are in principle equally good, and all are in principle equally subject to perversion and renewal" (Wolters, 1981:10-11).

In the light of the vagueness of the term "reason" we shall explain what rationality entails in terms of a distinction between conceptual knowledge and concept-transcending knowledge. This distinction will also open up a new understanding of rationalism and irrationalism.

1 Paul Bernays was the co-worker of the foremost mathematician of the 20th century, David Hilbert. He made this remark in his contribution to the Festschrift of Karl Popper. We shall return to this point below in our discussion of Kant's view of human understanding. 


\section{THE SOUL OR MIND CHARACTERISED BY REASON}

The faculty of reasoning or understanding (rationality) traditionally was seen as uniquely human. This view is still found in the currently prevailing biological classification, homo sapiens, the "wise man." In comparing humans and animals this legacy gives prominence to a striking difference between them. However, while maintaining the view that rationality ("reason") is the outstanding feature of the human "mind," 2 Darwin and neo-Darwinism at the same time argue for a continuity between lower animals, higher animals and human beings regarding their mental capacities: "We must also admit that there is a much wider interval in mental power between one of the lowest fishes, as a lamprey or lancelet, and one of the higher apes, than between an ape and man; yet this interval is filled up by numberless gradations" (Darwin, 1871 - electronic text without page markers). The word "gradations" gave rise to one of the general characterisations of Darwin's view: gradualism. $^{3}$

\section{THE GREEK DIALECTIC OF MATTER (BODY) AND FORM (SOUL)}

The close link between rationality (nous in Greek) and what was designated as the human soul resulted in the expression rational soul (anima rationalis in Latin). Aristotle distinguishes between a plant soul (anima vegetative), an animal soul (anima sensitiva) and the mentioned anima rationalis.

\subsection{Plato}

Initially Plato advanced a view of the human soul as something non-composite (simple) and indestructible. The soul is not only seen as the form and life-giving principle of a living entity, but also as an indivisible whole - derived from Aristotle's substance concept. ${ }^{4}$ The latter's hulèmorphism requires that the unity of being human is accounted for in terms of form and matter. In Fragment B 12 the pre-Socratic philosopher Anaxagoras portrays the nous ${ }^{5}$ as eternal (Fr. 14) and as having (autonomous) dominion over the disordered matter-germs because it is not intermingled with them. The nous possesses all knowledge and the greatest power ( $\pi \alpha \dot{v} \tau o v$ vov $\kappa \rho \alpha \tau \varepsilon \imath$ ), and its rule is extended over the rotating movement to which it gave the first impetus.

After Plato introduced his idea of the human soul in his dialogue Phaedo he proceeded in Politeia (436 ff.) by dividing the soul up into three parts, namely the logistikon, thumoeides and epithumétikon, i.e., thought, fervour and desire. During the middle ages thought, will and feeling continued to be appreciated as faculties of the soul. More recently we may compare it with Hitler's estates in Nazi Germany and the id, ego and superego in the depth psychology of Sigmund Freud.

This three-fold conception of the soul provides the basis for Plato's theory of the state and lays the foundation for his understanding of the first three cardinal virtues he distinguishes. According to this, wisdom (sophia) is the virtue of the rational part of the soul, courage (andreia)

2 In his Descent of Man Darwin writes: "Of all the faculties of the human mind, it will, I presume, be admitted that Reason stands at the summit" (Darwin, 1870). This view is deeply seated in the history of philosophy.

3 We shall return to this view below.

4 Bos points out that the word 'organikon' in Aristotle's thought has always been misunderstood. See Bos, 2003:85 ff., 93-94, 107-108, 162, 174, 200. The word "organikon" is used in the sense of "instrumental" or "serving as an instrument."

5 According to Anaxagoras the nous is not determined by any limits; it is not intermingled with germs of

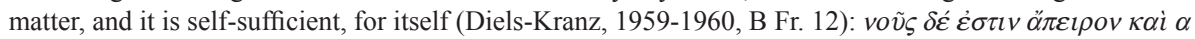

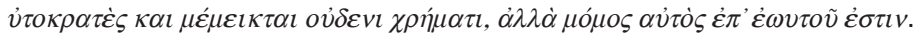


is the virtue of the spirited part, while temperance as virtue represents - under the rule of the rational part - the union of the thumoeides and the epithumétikon. Justice, as general virtue, embraces the former three, and thus also has a bearing on the ideal state as a whole (cf. Politeia, $433 \mathrm{~A}-\mathrm{C})$. Justice prohibits the transgression of the legal domain of the different parts of the soul, i.e. (abbreviations accepted?), it demands avoiding any legal excess - which also applies to the three estates within the state (cf. Politeia, $443 \mathrm{ff}$.).

\subsection{Aristotle}

Aristotle considers the nous to be separated from the body, yet the eternity of the nous does not coincide with the human soul and understanding residing in it. Ter Horst points out that in the thought of Aristotle the active nous threatens to break apart the substantial unity of form and matter, of the human substance.

\section{THE MEDVIEVAL SYNTHESIS - THE SUBSTANCE CONCEPT}

The after-effect of Greek philosophy during the middle ages is particularly found in the dualistic understanding of human beings, in the view that an immaterial soul is joined to a material body. The original Aristotelian view was that only the combination of soul (essential form) and body (matter) constitutes a substance, the human being. The substantial unity of the human being is therefore composed of form and matter.

This dualism became explicit in the view of Thomas Aquinas, for the latter accepted an active immaterial instance, the active understanding (Ter horst, 2008:23). Aristotle at least intended to defend the unity of form and matter (body and soul). In order to accommodate the Roman Catholic church doctrine, Thomas Aquinas had to acknowledge the "indestructibility" of the human soul as an independent substance. Still adhering to the initial view of Anaxagoras, Thomas Aquinas also holds that the intellectual principle can only know (material) bodies if it is not intermingled with them: "Therefore, if the intellectual principle contained within itself the nature of body, it would be unable to know all bodies." ${ }^{6}$ To this he adds: "Therefore the intellectual principle, which we call the mind or the intellect, has essentially an operation in which the body does not share. Now only that which subsists in itself can have an operation in itself. ... We must conclude, therefore, that the human soul, which is called intellect or mind, is something incorporeal and subsistent" (Pegis, 1945-I:685). The attempt to synthesise the Aristotelian substance concept with his own view, according to which the soul is supposed to be an independent substance and at the same time merely the form of the material body resulted for Thomas in serious problems. He accepted, after all, the Aristotelian view that "all things that are many in number have matter" (Metaph. 1074 a 33-34; Aristotle, 2001:884). So, if the soul is immaterial and if there is a multiplicity of souls, then "being many in number" entails that the immaterial souls must have matter! ${ }^{7}$

In line with the Aristotelian view the relationship between soul and body is seen as that between act and potency. To Aristotle act and potency are not only instantiated as form and matter, for they are eternal, supra-temporal and without becoming, indeed mutually irreducible principles. For this reason Aristotle's God, equated with pure activity (from Thomas Aquinas up to Jaspers and Barth also designated as actus purus), is just a final cause and not a Creator in the

6 See Thomas Aquinas, Summa Theologica I, Q.75 Art.2 as translated in Pegis, 1945-I:685.

7 Because there are multiple view on the position taken by Thomas Aquinas in connection with the interconnection of a material body and a form soul a reference to the original views of Thomas is desirable, as it is done in the text. In addition the recent work of Ter Horst is also mentioned to show that there are contemporary scholars underscoring these problems in the thought of Thomas Aquinas. 
biblical sense of the word (see Ter Horst, 2008:29).

The "simple" soul of Plato, the indivisible form of Aristotle, and the subsisting soul substance in the thought of Thomas Aquinas continued to play a role also in modern philosophy. The context in which the Cartesian cogito (I think) is positioned, embodies the switch from GreekScholastic realistic metaphysics to the modern nominalistic orientation motivated by the ideal to be free and autonomous personality while using a deterministic understanding of reality.

\section{THE MODERN TRUST IN REASON}

\subsection{Descartes: methodical doubt}

Descartes, with his well-known methodical scepticism, affirmed the autonomy of the thinking subject as the ultimate starting-point for philosophical thought and thus paved the way towards the modern trust in reason. He carried through the consequences of denying any universality outside the human intellect. The most important implicit implication of this nominalistic orientation is that it does not acknowledge any order transcending the human being as such. A universal law-order for creatures and also the orderliness of such creatures (which are subjected to creational laws), are transposed to the human mind. The seemingly innocent remark that "number and all universals are only modes of thought" (Descartes, The Principles of Philosophy, LVIII - see Descartes 1965:187) contains the radical reorientation caused by nominalism (Descartes therefore is no longer a realist).

In the mould of this new spiritual climate the "world" no longer embraces the human being. Rather, it is projected and seen as an entity, an object, at the disposal of the autonomously free rational human being. The vicious circle present in the proof used by Descartes for the existence of God actually demonstrates his ultimate trust in human reason. Having found his point of departure in the cogito ( $I$ think) he proceeds under the guidance of the maxim that rational thinking ought to be clear and distinct. In his Meditations III he takes as a "general rule, that all that is very clearly and distinctly apprehended (conceived) is true." However, the fundamental question is: What guarantees the truth of clear and distinct thought? (Descartes, 1965:95-96.)

Descartes answers:

And the whole force of the argument of which I have here availed myself to establish the existence of God, consists in this, that I perceive I could not possibly be of such a nature as I am, and yet have in my mind the idea of a God, if God did not in reality exist, - this same God, I say, whose idea is in my mind-that is, a being who possesses all those lofty perfections, of which the mind may have some slight conception, without, however, being able fully to comprehend them, - and who is wholly superior to all defect [and has nothing that marks imperfection]: whence it is sufficiently manifest that he cannot be a deceiver, since it is a dictate of the natural light that all fraud and deception spring from some defect (Descartes, 1965:110).

If God cannot be a "deceiver," how do we know that he really does exist? In order to answer this question Descartes once again appeals to the maxim of clear and distinct thought:

... the idea by which I conceive a God [sovereign], eternal, infinite [immutable], all-knowing, all-powerful, and the creator of all things that are out of himself, - this, I say, has certainly in it more objective reality than those ideas by which finite substances are represented (1965:100).

As long as one thinks clearly and distinctly (and do not allow the will to distract one from this path), one cannot be deceived and whatever is apprehended is always true - because it will not deceive us. Of all the ideas in the human mind the idea of God is the clearest and most distinct of all of them, hence God must exist. The vicious circle is 'clear(!)': that God exists is seen 
through clear and distinct thinking. Why is clear and distinct thinking true? Because God ensures us that clear and distinct thinking will not deceive us. Thus the existence of God is dependent upon the truth of clear and distinct thinking while the truth of clear and distinct thinking is dependent upon the non-deceiving God! ${ }^{8}$ Von Weiszäcker has a sound understanding of the spirit of modernity operative in Descartes' approach. Descartes reaches certainty about God not by considering the world, but by focusing upon himself (cf. Von Weizsäcker, 2002:130). In addition Von Weizsäcker says: "This state of affairs is characteristic of modernity. It is not the world in which I find myself that guarantees my existence. This guarantee is not lost, for when I recover the world then it is as the object of my self-assured thinking, that is to say, as an object which I can manipulate." 9

This circle actually unveils the fact that Descartes merely used his idea of God to impregnate his new mathematical method of analysis with the feature of infallibility. Underneath the methodical doubt leading to the conclusion: "I think, therefore I exist" (cogito ergo sum), one finds his deeply rooted modern trust ("faith") in the rationality of "reason." Unfortunately his argument is self-defeating. While doubting whatever otherwise seems to be true, he "discovered" that he cannot doubt that he is in doubt - which is a form of thinking - and from that basic fact he came to the affirmation of his own existence as a thinking being:

Accordingly, seeing that our senses sometimes deceive us, I was willing to suppose that there existed nothing really such as they presented to us; and because some men err in reasoning, and fall into paralogisms, even on the simplest matters of geometry, I, convinced that I was as open to error as any other, rejected as false all the reasoning I had hitherto taken for demonstrations; and finally, when I considered that the very same thoughts (presentations) which we experience when awake may also be experienced when we are asleep, while there is at that time not one of them true, I supposed that all the objects (presentations) that had ever entered into my mind when awake, had in them no more truth than the illusions of my dreams. But immediately upon this I observed that, whilst I thus wished to think that all was false, it was absolutely necessary that I, who thus thought, should be somewhat; and as I observed that this truth, I think, hence I am, was so certain and of such evidence, that no ground of doubt, however extravagant, could be alleged by the sceptics capable of shaking it, I concluded that I might, without scruple, accept it as the first principle of the philosophy of which I was in search (Descartes, 1965:26-27).

His argument disqualifies every possible perception or observation and all arguments formerly taken to be reliable and true. Yet he then says: "But immediately upon this I observed that, whilst I thus wished to think that all was false ..." This remark demonstrates that amongst all the doubtful observations he suddenly elevated one observation above all doubt, thus revealing his ultimate trust in reason!

\subsection{Kant: subjecting law and religion to the scrutiny of reason}

This deep trust in reason inspired the $18^{\text {th }}$ century German philosopher, Immanuel Kant, in the Foreword to the first edition of his Critique of Pure Reason (1781), to explain the penetrating aim of rational critique. He holds that not even law in its majesty or religion in its sanctity are allowed to withdraw themselves from the critical scrutiny of reason, for reason can only show respect to

8 The article on Descartes in the Standford Encyclopedia of Philosophy does not contemplate the form in which I have demonstrated the circle in the thought of Descartes (see http://plato.stanford.edu/entries/ descartes-ontological/. See Lawrens, 2011.

9 "Dies ist ein charakteristisch neuzeitlicher Sachverhalt, Nicht die Welt, in der ich mich vorfinde, garantiert mein Dasein. Diese Garantie geht nicht verloren, und wenn ich die Welt wiederfinde, dann als Gegenstand meines selbstgewissen Denkens und darum als Objekt, das ich hantieren kann" (Von Weizsäcker, 2002:130-131). 
that which has withstood its critical assessment: "Our age is, in every sense of the word, the age of criticism and everything must submit to it. Religion, on the strength of its sanctity, and law on the strength of its majesty, try to withdraw themselves from it; but by doing so they arouse just suspicions, and cannot claim that sincere respect which reason pays to those only who have been able to stand its free and open examination" (Kant, 1781:A-12 - translation F.M. Müller see Kant 1961:21).

\subsection{Understanding as the a priori formal law-giver of nature}

The overestimation of human understanding present in the thought of this extremely influential Enlightenment philosopher cannot be understood properly apart from the background of the rise of the modern natural sciences. In formulating his famous law of inertia Galileo exerted a strong influence on the way in which Kant elaborated this idea in his view of thought categories. In his famous 1638 treatise on "Two New Sciences," Galileo used a historically significant thought experiment (see Galileo, 1973). He contemplated the movement of a body in motion, on a path extended into the infinite, and then argued that this body will continue its motion on this path indefinitely if nothing impedes its motion (friction, for example).

Kant pursued this path by accrediting human understanding with an incredible capacity. If it is indeed possible for Galileo to formulate a thought experiment merely on the basis of the spontaneous subjectivity of human theoretical thinking, and that the human subject subsequently succeeds in deducing a natural law from this mere thought experiment - namely the kinematical law of inertia - then this must imply that there are elements in our knowledge prior to all experience (i.e., a priori elements). What is even more "astounding," according to Kant, is that these a priori elements in the human mind actually make possible our knowledge of reality in the first place.

The "solution" suggested by Kant is therefore that these laws of nature are not derived from nature, since, as categories of thought, they are prescribed to nature in an a priori way. This indeed represents what has become known as the crucial Copernican turn in modern epistemology (theory of knowledge) - in ascribing the primacy no longer to the "object," but to the thinking human subject! That this "turn" gave birth the new motive of logical creation is seen in the rise of various thought experiments in modern philosophy. Thomas Hobbes, for example, portrays such a thought experiment in his work De Corpore where he envisages a break-down of reality into a heap of chaos such that human understanding subsequently can create a new cosmos by using the basic concept of a moving body. Early modern and modern theories of the (hypothetical) state of nature are also rational reconstructions and not historical accounts. We shall refer in particular below to a thought experiment of Galileo which exerted an influence upon this motive of logical creation carried to its extreme in the thought of Kant.

Kant was aware of the difficulties involved in this Copernican turn, for he contemplated the question how "subjective conditions of thought can have objective validity, that is, can furnish conditions of the possibility of all knowledge of objects"? (see Kant, 1787-B:122). Kant advanced the radical humanistic conclusion: the laws of nature are a priori contained in the subjective understanding of the human being:

... the categories are conditions of the possibility of experience, and are therefore valid a priori for all objects of experience (Kant, 1787-B:161); Categories are concepts which prescribe laws a priori to appearances, and therefore to nature, the sum of all appearances (Kant, 1787-B:163); Understanding creates its laws (a priori) not out of nature, but 
prescribes them to nature (Kant, 1783, II:320; § 36)..$^{10}$

Human understanding is thus promoted to become the (a priori) formal law-giver of nature in a universally valid way. In order to understand this view properly a brief explanation of what rationalism entails may be helpful. The core of rationality is found in the conceptual element ${ }^{11}$ and what enables the acquisition of concepts is given in the presence of universal features. By means of logical-analytical identification and distinguishing a multiplicity of universal traits are combined in the unity of a concept. But what is individual exceeds the grip of concepts for concepts are "blind" to what is unique. ${ }^{12}$

Within Kant's thought the ancient view of the simple soul, precluding multiplicity, survived in his view of the cogito, the synthesising unity of consciousness. The representation "I am" cannot contain any multiplicity because then it would not be able to accomplish its unifying function (Kant, 1787-B:138-139, 398).

\section{FROM A UNIVERSALLY REASON TO HISTORICAL RELATIVITY}

By the end of the $18^{\text {th }}$ century and the early $19^{\text {th }}$ century Kant's view was challenged through the relativity introduced by the emphasis on unique historical events. The supposedly universally valid construction of reality by the human subject eventually also became a victim of the relativistic consequences of this historicism which claimed that moral standards, legal norms, aesthetic values and even religious convictions are all caught up in the ever-flowing stream of historical change. In 1922 Troeltsch declared: "We see here everything in the flow of change, in endless and constantly new individualisation, in its being determined by the past and in the direction toward an unknown future. State, law, morality, religion and art are dissolved in historical change and they are everywhere only understandable as ingredients of historical developments."13

Through historicism the universal validity assigned by Kant to his thought categories was relativised. This process was accompanied by so-called linguistic turn (by the end of the $19^{\text {th }}$ century and the beginning of the $20^{\text {th }}$ century) which eventually settled for a personally or socially constructed world - each person or each society constructs its own unique life-world. If the emphasis falls upon language, the additional qualification is that every person or society gives its own meaning to the world - an approach particularly advocated by postmodernist thinkers. Yet, during the first part of the $20^{\text {th }}$ century positivism and neo-positivism returned to the earlier Enlightenment trust in reason in claiming that sensory perception and logical constructs are objective and neutral.

10 Its is worth-while to quote the original German formulation of this last statement as well: "der Verstand schöpft seine Gesetze (a priori) nicht aus der Natur, sondern schreibt sie dieser vor."

11 Earlier we have noted that Bernays holds that the "proper characteristic of rationality" is "to be found in the conceptual element" (see Bernays, 1974:601).

12 From the fact that one cannot obtain conceptual knowledge of what is individual and unique, it does not follow that what is individual cannot be known. It can be known by means of concept-transcending knowledge or idea-knowledge. Irrationalism reifies idea-knowledge, i.e., what is indiviual and unique is appreciated at the cost of what is universal. Adorno, for example, in a typical irrationalist way attempts to be liberated from the grip of the universal, while Plotinus, by contrast, assigns priority to what is universal - typical of rationalism - and for this reason believed that what is individual cannot be comprehended (see Plotinus, 1956:VI, 3, 9, 36; VI, 2, 22).

13 "Wir sehen hier alles im Flusse des Werdens, in der endlosen und immer neuen Individualisierung, in der Bestimmtheit durch Vergangenes und in der Richtung auf unerkanntes Zukünftiges. Staat, Recht, Moral, Religion, Kunst sind in den Fluss des historischen werdens aufgelöst und uns überall nur als Bestandteil geschichtlicher Entwicklungen verständlich” (Troeltsch, 1922:573). 


\section{THE LIMITATIONS OF POSITIVISM: IS THE UNIVERSE RATIONAL AND DOES IT DISPLAY A MATHEMATICAL STRUCTURE?}

What positivism nonetheless did not realise is that sensory perception relates to things and events, to the concrete what of experience, but that it does not give access to the terms employed in describing the how of what has been observed, for these terms actually stem from the various modal aspects of reality. And these modal functions as such are never open to sensory perception. Yet, these aspects provide theoretical thinking with modal terms (aspectual terms) that are indispensable for the formation of scientific concepts and theories. As soon as the inevitability of employing modal terms is acknowledged (within physics we find, for example, the quantitative term mass, the spatial term field, the kinematic term movement (sometimes associated with time) and the physical term energy), the Achilles' heel of positivism is laid bare. The key question is whether these modal aspects could be observed in a sensory way? Can they be weighed, touched, heard or smelled? The answer must be negative, for they are not things but aspects within which concretely existing things function. Uprooting itself positivism therefore had to digest "sense data" theoretically with the aid of terms that are not open to sensory perception! ${ }^{14}$

It is remarkable to note here that the rationalistic (modernist) conviction of Kant, as seen in his above-mentioned identification of the structure of the universe with human rationality (human understanding as the a priori formal law-giver of nature), is still conquering the minds of $20^{\text {th }}$ century scholars. Davies is quoted by Van Huyssteen as referring to the "fact that the rational nature of our universe is reflected in its basic mathematical structure" (quoted by Van Huyssteen, 1998:71). Three pages earlier Van Huyssteen said: "What is astounding, however, is to what extent our world is truly rational, i.e., in conformity with human reason" (Van Huyssteen, 1998:68). On this point Van Huyssteen simply continues the rationalistic (modernist) legacy which does not distinguish between ontic features of reality and the concepts we form of them. The view that concepts are formed on the basis of universal traits does not entail that these ontic properties themselves are rational in nature $!^{15}$

\section{SUPRA-THEORETICAL COMMITMENTS}

The mere fact that all academic disciplines, to a larger or lesser degree, is burdened by alternative and often conflicting theoretical paradigms (mathematics and physics included), shows that (theoretical) reason does not have the last word in scholarly endeavours. Stegmüller emphatically states: "A self-assurance of human thought is excluded, wherever one may consider it. One can never reach a positive result without pre-suppositions. One has to believe in something in order to justify something else" (Stegmüller, 1969:314). ${ }^{16}$

14 The renowned physicist, Max Planck, who eventually became sharply critical of Mach's positivism, distinguished between the real outside world, the world of the senses and the (theoretical) world of the science of physics, which he equates with the "physikalisches Weltbild" (the physical world picture) (Planck, 1973:208). The abstractions that belong to the 'Weltbild' are not sensorily perceptible - they embrace, according to him, the known law-conformities and concepts such as space, time and causality (see Vogel, 1961:149).

15 This position is taken while at the same time an equally forceful attempt is made throughout the work to hold on to a postmodern perspective.

16 Van Huyssteen correctly emphasizes the committed nature of rational thought in the sense that it is rooted in supra-theoretical convictions: "The high degree of personal involvement in theological theorizing not only reveals the relational character of our being in the world, but epistemologically implies the mediated and interpretative character of all religious commitment, which certainly is no 
The prevailing implicit trust in reason did not realise that such a trust or faith in reason is not itself rational! Twentieth century philosophers from different philosophical traditions started to acknowledge this fact. The well-known philosopher of science, Sir Karl Popper, radically attacks an uncritical or comprehensive rationalism based upon "the principle that any assumption which cannot be supported either by argument or by experience is to be discarded" (Popper, 1966II:230). He argues that this kind of rationalism is demonstrably inconsistent, i.e., in terms of its own criteria: since "all arguments must proceed from assumptions, it is plainly impossible to demand that all assumptions should be based on argument" (Popper, 1966-II:230). Popper is aware of the fact that behind the idea of an "assumptionless" approach, a huge assumption hides itself - something eventually also criticised by the prominent hermeneutical philosopher, Hans-Georg Gadamer, in his mocking of the prejudice of Enlightenment against prejudices (cf. Gadamer, 1989:276).

Popper's own position unequivocally demonstrates his insight into the self-insufficiency of "rationality." He knows that the rationalistic trust in reason is not rational itself, and explicitly speaks of "an irrational faith in reason" - which means that, according to him "rationalism is necessarily far from comprehensive or self-contained" (Popper, 1966-II:231).

The dualism in Kant's thought between the domain of the classical science ideal (restricted to phenomena) and the ideal of a free and autonomous personality (as a noumenon), that is, between nature and freedom, provides to basis for his dualism between is and ought, as well as that between science and faith. Kant holds: "I had to restrict knowing in order to make room for faith." 17

Stegmüller reacts sharply to this dualism: "A person does not have to set aside knowledge in order to make room for faith. Much rather one already has to believe something if he wants to speak of knowing and science at all." 18 He furthermore asserts that an ultimate certainty is required, for without that it would be impossible even to start. "Some form of an absolute knowledge must exist; without it would not have been able to begin"; "We must already 'possess' absolute evidence, that is we must already believe in it, ..."19

And then Stegmüller presents his unique characterisation of the relationship between science and faith. "In science one believes, in religion one knows (or: one claims to know)."20

\section{THE CONTINUITY POSTULATE OF THE MODERN HUMANISTIC SCIENCE-IDEAL}

The unbridled trust in the capacities of human reason that permeated modern philosophy since the Renaissance included the belief that there are no limits, boundaries or gaps (discontinuities) that cannot be bridged in thought. The above-mentioned thought experiments breathe the spirit of an autonomous reason which is capable to answer the ultimate questions in life by reducing whatever there is to one or another basic denominator. Since Leibniz introduced his law of continuity (lex continui) its combination with the modernist motive of logical creation

irrational retreat to commitment, but on the contrary reveals the committed nature of all rational thought, and thus the fiduciary rootedness of all rationality" (Van Huyssteen, 1997:44).

17 "Ich mußte also das Wissen aufheben, um zum Glauben Platz zu bekommen" (Kant, 1787-B:xxx).

18 "Man muss nicht das Wissen beseitigen, um den Glauben Platz zu machen. Vielmehr muss mann bereits etwas glauben, um überhaupt von Wissen und Wissenschaft reden zu können” (Stegmüller, 1969:33 -

Neue Einleitung).

19 "Irgendein absolutes Wissen muß es geben; ohne dieses könnten wir überhaupt nicht beginnen";

“Absolute Evidenz müssen wir schon 'haben', d.h. wir müssen an sie bereits glauben, ...” (Stegmüller,s 1969:194).

20 Stegmüller, 1969:212: “... in der Wissenschaft wird geglaubt, in der Religion weiss man (oder: behauptet man, zu wissen)". 
nurtured the belief that nature does make leaps: natura non facit saltum. This attitude became manifest in the attempt to subsume all of reality, the entire universe, under one or another principle of explanation. It could be discrete monads according to Leibniz, his spatially oriented lex continui itself, movement (Galileo and Hobbes), physical causality (partly defended by Kant - in connection with the phenomena), or die basic denominator of perceiving (Locke, Berkeley and Hume). ${ }^{21}$

The two most dominant domains within which the trust in reason manifested itself is that of cosmology - the "Big Bang" theory viewed as an account of creation - and the (neo-)Darwinian theory of evolution.

\section{DARWIN'S A PRIORI FAITH IN CONTINUOUS CHANGE (GRADUALISM)}

Darwin's first reference to natura non facit saltus is slightly critical of it, for he speaks of "that old, but somewhat exaggerated, canon in natural history of 'Natura non facit saltum' " (Darwin, 1859a:116). But soon, by broadening his perspective to include the known and unknown inhabitants of the past time, this "old canon" is depicted as "strictly true" (Darwin, 1859a:124). Darwin increasingly became confident that this continuity postulate must bridge all gaps in an a priori fashion: "As natural selection acts solely by accumulating slight, successive, favourable variations, it can produce no great or sudden modifications; it can act only by short and slow steps. Hence, the canon of 'Natura non facit saltum,' which every fresh addition to our knowledge tends to confirm, is on this theory [simply - Darwin, 1859:444445] intelligible" (Darwin, 1859a:307). He also phrases this continuity postulate in the following terms: "Natural selection acts only by the preservation and accumulation of [infinitesimally Darwin, 1859:142] small inherited modifications" (Darwin, 1859a:56).

Darwin's a priori trust in the validity of the continuity postulate builds upon the idea of "infinitesimally small inherited modifications." Darwin is willing to sacrifice his entire theory if the assumed continuity may turn out to be absent. "If it could be demonstrated that any complex organ existed, which could not possibly have been formed by numerous, successive, slight modifications, my theory would absolutely break down" (Darwin, 1859a:109). Moreover, Gould calls upon Gruber, Barrett and Mayr who also noted the centrality of gradualism in Darwin's thought and even remarks that by following his chief guru, Charles Lyell, Darwin equated gradualism with rationality.

Darwin's trust in this continuity postulate was accompanied by the honest acknowledgement that the required empirical evidence is lacking. "But just in proportion as this process of extermination has acted on an enormous scale, so must the number of intermediate varieties, which have formerly existed, be truly enormous" (Darwin, 1859a:196). To which (on the same page) he adds the significant question: "Why then is not every geological formation and every stratum full of such intermediate links?"

In spite of this honest question, which is still valid today, Darwin left his followers with an $a$ priori faith in continuous or gradual change, a conviction that resulted in what has been alluded to above, his gradualism. As an a priori postulate of theoretical reason the idea of continuity

21 "To hate, to love, to think, to feel, to see; all this is nothing but to perceive" (see Hume, 1739, 1,2,6). The famous dictum if Berkeley is: esse est percipi (to be is to be perceived). The continued existence of an entity, when no human agent perceives it, is therefore guaranteed by God as an ever-perceiving mind: "That is to say, that there are certain permanent and distinct parcels of Matter, corresponding to our ideas, which, though they do not excite them in our minds, or anywise immediately affect us, as being altogether passive and unperceivable to us, they are nevertheless to God, by whom they are perceived, as it were, so many occasions to remind Him when and what ideas to imprint on our minds - that so things may go on in a constant uniform manner" (Berkeley, 1969:100). - not listed in references 
failed to appreciate what the fossil record revealed - that types appear suddenly fully formed, continue to exist for millions of years, and then abruptly disappears. Gould points out that these discontinuous stasis lines ${ }^{22}$ are data that cannot be explained away: Eldredge and Gould wrote in 1977: "It is time for evolutionary theory to catch up with empirical paleontology, to confront the phenomenon of evolutionary non-change, ... , rather than simply explain it away" (Gould, 2002:752).

What was needed was an approach that "could validate the primary signal of the fossil record as valuable information rather than frustrating failure" (Gould, 2002:760-761). The general assessment of Gould is truly astonishing: "I believe, therefore, that Darwin's strong, even pugnacious, defence of strict gradualism reflects a much more pervasive commitment, extending far beyond the simple recognition of a logical entailment implied by natural selection" (Gould, 2002:151).

Owing to his knowledge of the philosophy of science of the 20th century Gould acknowledged the limitations of a given theoretical paradigm: "gradualism, having defined contrary data either as marks of imperfection or documents of disappointment, could not be refuted from within." Darwin and his followers who accepted his a priori continuity postulate ("gradualism") are quick in pursuing the escape-route of claiming that the fossil record is "imperfect." The predominance of the assumed continuity postulate justifies Gould's remark that we often fail to realise "how much of the Origin presents an exposition of gradualism, rather than a defence of natural selection" (Gould, 2002:151).

There is an obvious tension between millions of years of stasis and the assumed (continuous) changes caused by adaptation and natural selection. Stasis over millions of years would have had to endure numberless instances of environmental "attacks" with equally numerous instances of adaptive changes through the operation of natural selection. Yet the empirical (paleontological) fact is that this did not happen. Gould writes: "... if stasis merely reflects excellent adaptation to environment, then why do we frequently observe such profound stasis during major climatic shifts like ice-age cycles (Cronin, 1985), or through the largest environmental change in a major interval of time (Prothero and Heaton, 1996)?" (Gould, 2002:878).

However, it would exceed the confines of this article to explore the problems within (neo-) Darwinism, theistic evolution and the biblical understanding of humankind in more detail. We conclude our analysis therefore by briefly alluding to the conflict entailed in what is known as theistic evolution - between the progressive character of evolution and its lack of purpose in the original Darwinian understanding. These problems will be addressed in a separate article.

\section{THE PARADOX BETWEEN RANDOMNESS AND PROGRESS}

Gould portrays the tension between chance and progress as a paradox:

The problem that spawns this confusion within the Darwinian tradition may be simply stated as a paradox. The basic theory of natural selection offers no statement about general progress, and supplies no mechanism whereby overall advance might be expected. Yet both Western culture and the undeniable facts of a fossil record that started with bacteria alone, and has now exalted us, cry out in unison for a rationale that will place progress into the centre of evolutionary theory (Gould 1996:136).

He is quite honest in conceding "that the most knowledgeable students of life's history have always sensed the failure of the fossil record to supply the most desired ingredient of Western

22 However, as Berlinski remarks, "[M] ost species enter the evolutionary order fully formed and then depart unchanged" (Berlinski, 2003:158). 
comfort: a clear signal of progress measured as some form of steadily increasing complexity for life as a whole through time." To which he adds: "The basic evidence cannot support such a view, for simple forms still predominate in most environments, as they always have. Faced with this undeniable fact, supporters of progress (that is, nearly all of us throughout the history of evolutionary thought) have shifted criteria and ended up grasping at straws" (Gould 1996:167).

A similar paradox is present in the thought of Simpson for on the one hand he holds that the long "history of life is a slow interplay of material processes ... [Man] was not planned" and on the other that the "culmination of this sort of progress is man" (Simpson, 1953:155 ff.).

Perhaps the most difficult challenge to any theistic evolutionary "synthesis" is found in the question how God can "direct" and "undirected" process, and how to reconcile Genesis 1:26-28 and Psalm $8^{23}$ with the purposeless process of random mutations and natural selection. Darwin's indebtedness to the modern humanistic science ideal with its inherent continuity postulate cannot be reconciled with the biblical understanding of God and creation, for the underlying nominalistic spirit of (neo-)Darwinism denies any universality outside the human mind and by doing that it eliminates any and all God-given laws for creation. As Simpson articulates his opposition to type laws: "[O]rganisms are not types and do not have types" (Simpson, 1969:8).

Theistic evolutionism inevitably tends to drift towards an emergent evolutionistic and/or vitalistic position, thus unwittingly contradicting the (neo-)Darwinian view of evolution as a random (purposeless) process. However, we shall not here enter into a more detailed discussion of the problems entailed in the position of theistic evolution.

\section{CONCLUSION}

The Western intellectual legacy appears to be burdened by the demi-god reason. The claim to universality and objectivity conceals the reality of ultimate commitments giving direction to human thought. It is only when a proper distinction is made between Creator and creation that scholars are in principle liberated from bringing the honour destined for God to one or another creature which is deified as a substitute for God.

\section{LITERATURE}

Aristotle. 2001. The Basic Works of Aristotle. Edited by Richard McKeon with an Introduction by C.D.C. Reeve. (Originally published by Random House in 1941). New York: The Modern Library.

Berkeley, G.1969. The Principles of Human Knowledge, Edited and introduced by G.J. Warnock. Oxford: The Fontana Library (1710).

Berlinski, D. The Deniable Darwin. In: Campbell and Meyer, 2003 (pp.157-177).

Bernays, P. 1974. Concerning Rationality. In: The Philosophy of Karl Popper, The Library of Living Philosophers, Volume XIV, Book I. Edited by P.A. Schilpp. La Salle. Illimois: Open Court.

Bernays, P. 1976. Abhandlungen zur Philosophie der Mathematik. Darmstadt: Wissenschaftliche Buchgesellschaft. - was not used in text?

Bos, A.P. 2003. The Soul and its Instrumental Body, A Reinterpretation of Aristotle's Philosophy of Living Nature, Leiden-Boston: Brill.

Campbell, J.A. and Meyer, S.C. 2003. Darwinism, Design, and Public Education. East Lansing: Michigan State University Press.

Darwin, C. 1871. Descent of Man, available on the WEB: http://www.infidels.org/library/historical/charles_ darwin/descent_of_man/chapter_01.html (accessed on October 29, 2005).

Darwin, C. 2005. On the Origin of Species by Means of Natural Selection or the Preservation of favoured races in the struggle for life (1859a). WEB version: http://www.infidels.org/library/historical/charles_

23 The complexities surrounding our understanding of being created in the image of God is discussed in great detail in Middleton's work on this theme (see Middleton, 2005). 
darwin/origin_of_species/Intro.html (accessed on October 29, 2005).

Descartes, R. 1965. A Discourse on Method, Meditations and Principles, translated by John Veitch, Introduced by A.D. Lindsay. London: Everyman's Library.

Diels, H. and Kranz, W. 1959-60. Die Fragmente der Vorsokratiker. Vols. I-III. Berlin: Weidmannsche Verlagsbuchhandlung.

Gadamer, H-G. 1989. Truth and Method, Second Revised Edition (first translated edition 1975). New York: The Continuum Publishing Company.

Galileo Gallilei 1638. Dialogues and Mathematical Demonstrations concerning Two New Sciences, the German translation. Darmstadt: Wissenschaftliche Buchgesellschaft (1973).

Gould, S.J. 1977. Evolution's Erratic Pace. In: Natural History, Vol.86:5 (May 1977).

Gould, S.J. 1996. Life's Grandeur. London: Jonathan Cape.

Gould, S.J. 2002. The Structure of Evolutionary Theory. Cambridge, Massachusetts: The Belknap Press of Harvard University Press.

Hume, D. 1962. A Treatise of Human Nature. London: Collins, The Fontana Library (First published in 1739).

Kant, I. 1781. Kritik der reinen Vernunft, 1st Edition (references to CPR A). Hamburg: Felix Meiner edition (1956).

Kant, I. 1783. Prolegomena einer jeden künftigen Metaphysik die als Wissenschaft wird auftreten können. Hamburg: Felix Meiner edition (1969).

Kant, I. 1787. Kritik der reinen Vernunft, $2^{\text {nd }}$ Edition (references to CPR B). Hamburg: Felix Meiner edition (1956).

Kant, I. 1961. Critique of Pure Reason, Translated by F.M. Müller. New York: Dolphin Books.

Middleton, J.R. 2005. The Liberating Image. The Imago Dei in Genesis 1. Grand Rapids: Brazos Press.

Lawrence, N. 2011. "Descartes' Ontological Argument", The Stanford Encyclopaedia of Philosophy (Summer 2011 Edition), Edward N. Zalta (ed.), URL = <http://plato.stanford.edu/archives/sum2011/entries/ descartes-ontological/>

Pegis, A.C. 1945. Basic Writings of Saint Thomas Aquinas, Volumes I and II. New York: Random House.

Planck, M. 1973. Vorträge und Erinnerungen, $9^{\text {th }}$ reprint of the $5^{\text {th }}$ edition. Darmstadt: Wissenschaftliche Buchgesellschaft.

Plotinus, 1956. The Enneads. Translated by Stephan Mackenna. London: Faber

Popper, K. 1966. The Open Society and its Enemies, Vol. I \& II, London: Routledge \& Kegan Paul.

Simpson, G.G. 1953. Life of the Past. New Haven: Yale University Press.

Simpson, G.G. 1969. Biology and Man. New York: Harcourt.

Stegmüller, W. 1969. Metaphysik, Skepsis, Wissenschaft, $2^{\text {nd }}$ edition. Berlin/New York: Springer.

Ter Horst, G. 2008. De ontbinding van de substantie. Een deconstructie van de beginselen van vorm en materie in de ontologie en de kenleer van Thomas van Aquino. Delft: Uitgevrij Eburon.

Troeltsch, E. 1922. Die Krisis des Historismus. In: Die neue Rundschau 33:572-590. (Also contained in: Der Historismus und seine Probleme, Volume 4, of his Gesammelte Werke, Aalen 1961.)

Van Huyssteen, J.W.V. 1997. Essays in Postfoundationalist Theology, Grand Rapids: William B. Eerdmans Publishing Company.

Van Huyssteen, J.W.V. 1998. Duet or Duel? Theology and Science in a Postmodern World. Trinity Press International. Pennsylvania: Harrisburg.

Vogel, H. 1961. Zum Philosophischen Wirken Max Plancks. Seine Kritik am Positivismus. Berlin: AkademieVerlag.

Von Baader, F. 1921. Fermenta Cogitationis, in: Schriften Franz Von Baaders, Selected and Edited by Max Pulver, Leipzig: Im Insel-Verlag.

Von Weizsäcker, C.F. 2002. Große Physiker, Von Aristoteles bis Werner Heisenberg. München: Deutscher Taschenbuch Verlag.

Wolters, A. 1981. Facing the Perplexing History of Philosophy. In: Journal for Christian Scholarship, 17(4):131.

\section{KEY WORDS}

(Trust in) Reason

(Ir)rationaslism

conceptual knowledge 
concept-transcending knowledge continuity postulate natural science ideal

\section{TREFWOORDE}

(Vertroue in) rede

(Ir)rasionalisme

begripskennis

begripstransenderende kennis

kontinuïteitspostulaat

natuurwetenskapideaal 